\title{
Southern Australian endemic and semi-endemic foraminifera: a preliminary report
}

\author{
QIANYU LI ${ }^{1}$, PATRICK G. QUILTY ${ }^{2}$, GRAHAM MOSS ${ }^{1,3}$ \& BRIAN MCGOWRAN ${ }^{1}$ \\ ${ }^{1}$ Department of Geology \& Geophysics, The University of Adelaide, SA 5005, Australia. \\ ${ }^{2}$ Australian Antarctic Division, Channel Highway, Kingston, Tasmania 7050, Australia. \\ ${ }^{3}$ Present address: Marine Geoscience \& Petroleum Geology Program, Australia Geological Survey Organisation, \\ Canberra ACT 2601, Australia.
}

\begin{abstract}
The Cenozoic in southern Australia contains many foraminifera endemic to the region in neritic (intermediate- to shallow-water) facies. They were mostly epifaunal and inhabited waters to some $300 \mathrm{~m}$ deep. This endemism is first obvious in the later Eocene when Maslinella, Crespinina and Wadella, among others, evolved. More than half of the Eocene endemic species disappeared in the Eocene or Oligocene. There followed in the Oligocene the evolution of such species as Parrellina imperatrix and Astrononion centroplax. The Miocene was a time of slightly reduced endemism and is characterized by migration into the region of many larger (sub)tropical taxa such as Lepidocyclina and Cycloclypeus. The long-ranging genus Notorotalia emerged about $50 \mathrm{Ma}$ ago and is still common in modern southern mid-latitude waters. The youngest common extant species which made their first appearance in the Pliocene-Quaternary include Discorbis dimidiatus and Parredicta porifera, both with a test up to $1.5 \mathrm{~mm}$ in diameter. A similar pattern has been recorded in New Zealand.

Four phases of endemism can be recognized: later Eocene, Oligocene, Miocene and PlioceneQuaternary. It appears that the four phases were all stimulated in response to major marine transgressions, respectively the Wilson Bluff $(=$ Khirthar $)$, Aldingan, Clifton-Longfordian and Hallet Cove--Glanville transgressions. Probably they signal four important stages in the transformation of water masses along the southern continental margin. J. Micropalaeontol. 15(2): 169-185, October 1996.
\end{abstract}

\section{INTRODUCTION}

A large onshore and offshore area along the passive continental margin of southern Australia is covered by Cenozoic marine sequences dating from the late Palaeocene to Holocene (McGowran, 1979, 1991a,b). Since the 1960s, detailed studies of planktonic foraminifera have improved understanding of the regional biostratigraphy, making possible a closer, though slightly imperfect, correlation of local strata to global standard chronobiostratigraphy and sequence stratigraphy (e.g. Jenkins, 1960; Heath \& McGowran, 1984; Carter, 1990; McGowran et al., 1992: McGowran \& Li, 1993; Li \& McGowran, 1996). This biostratigraphic framework provides chronological control in the interpretation of micro- and macro-fossil palaeoecology, as well as the reconstruction of palaeoenvironments and background for the understanding of the origin of the modern fauna. Major Tertiary sedimentary basins in southern Australia are shown in Fig. 1, and local biostratigraphy in Fig. 2.

These Tertiary deposits contain many taxa of benthic foraminifera which are endemic to southern Australia. Others, or semi-endemic species, occur in a wider region, in New Zealand or around the temperate belt in the Southern Hemisphere. Although the occurrence of endemic species has been known for decades, little attention has been focussed on their palaeoecological and palaeoenvironmental significance. Here we summarize what is now known of endemism in the Cenozoic foraminifera of Australia and discuss the broad biostratigraphic potential and general palaeoecology of these endemic species based on limited information of their distribution.

One of the few comments on the affinities of Australian
Tertiary foraminifera is that by Crespin (1948) who reviewed briefly the influence of Indo-Pacific warm water incursions into the Australian Tertiary sequences. At the time, a general knowledge that we now have of endemism was lacking. Our report on the origins and affiliations of some special Australian foraminifera will contribute to the understanding of regional biological diversity, a topic of increasing general interest (Beattie, 1995).

We are limited by the fact that the southern Australian marine sediment record has major gaps, and also that so many of the smaller species are as yet undefined. Compared with commercially significant sections in many other continents, the southern Australian record has been poorly studied. It is clear that some of the conclusions made here will be altered in the light of new discoveries and modification of our current views on synonymy. However, we believe that our efforts are worthy for snapping a generalized picture of the foraminiferal distribution in the region.

Records from our own observations and from the following publications were used to compile the species database: Howchin (1889), Chapman (1907, 1941), Chapman et al. (1934), Parr (1932, 1939, 1942, 1950), Crespin (1950), Carter (1958, 1964), Ludbrook (1961), Quilty (1974, 1977a, 1980, 1981, 1982) and Chaproniere (1984). Selected endemic and semi-endemic species are listed in the Appendix.

THE ENDEMIC SPECIES: TYPES AND NUMBER

The term 'endemic' has been defined for biological purposes as 'a species or family confined to a particular region and thought to have originated there' (Walker, 1988) and is 


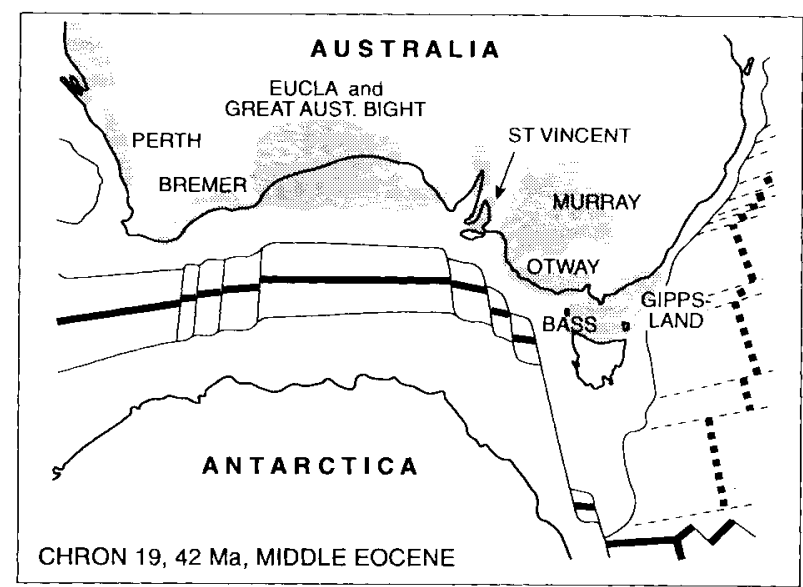

Fig. 1. Southern Australia in the later middle Eocene, showing major sedimentary basins (fide McGowran, 1991a). Slightly prior to this time, the separation of Australia from Antarctica accelerated; as a result, these basins were formed and started to receive sediments.

employed here in that sense. It is the opposite of 'cosmopolitanism'.

Apart from cosmopolitan forms, three groups of benthic foraminifera can be recognized in southern Australia: endemic sensu stricto, semi-endemic and migratory. They refer respectively to species known existing only in southern Australia (endemic s.s.), in both southern Australia and New Zealand or even South America (semi-endemic), and those migrating into Australian waters from the tropics and subtropics during warmer times (migratory). The term (semi)endemic is used here to include both truly endemic and semi-endemic forms. Table 1 lists some examples of these species groups.

Many species are facies-controlled and therefore reflect palaeoecological differences. What is discussed here, however, is their occurrence in certain sedimentary sequences, or in all rocks of a similar age. Facies changes are considered as important in affecting species of a single genus within a short period of time, but not so when a collective age range of these species is concerned.

No exact number of the species endemic to southern Australia has been documented due to the fact that many species once thought to be Australian or Australasian have been found to occur elsewhere, and vice versa. This is particularly true for those rare and/or small forms, which are easily overlooked in routine examinations with a low-powered, binocular microscope. The unilocular Duoforisa, for instance, can only be identifed with scanning electron microscope as having two apertures on both ends of its tiny ovular test (Pl. 1, Figs 1, 2). This Oligo-Miocene genus, together with its two species, is considered to be new and endemic because no similar forms have been reported from elsewhere (Li \& McGowran, 1994). Another example is a discorbid, found in the Oligocene, which mimics the test of the Holocene Colonimilesia obscura McCulloch but has 3-5 (instead of one) spines on each chamber (Pl. 1, Figs 7, 8). We believe that this Oligocene discorbid belongs in Colonimilesia, thus extending the range of this genus to the

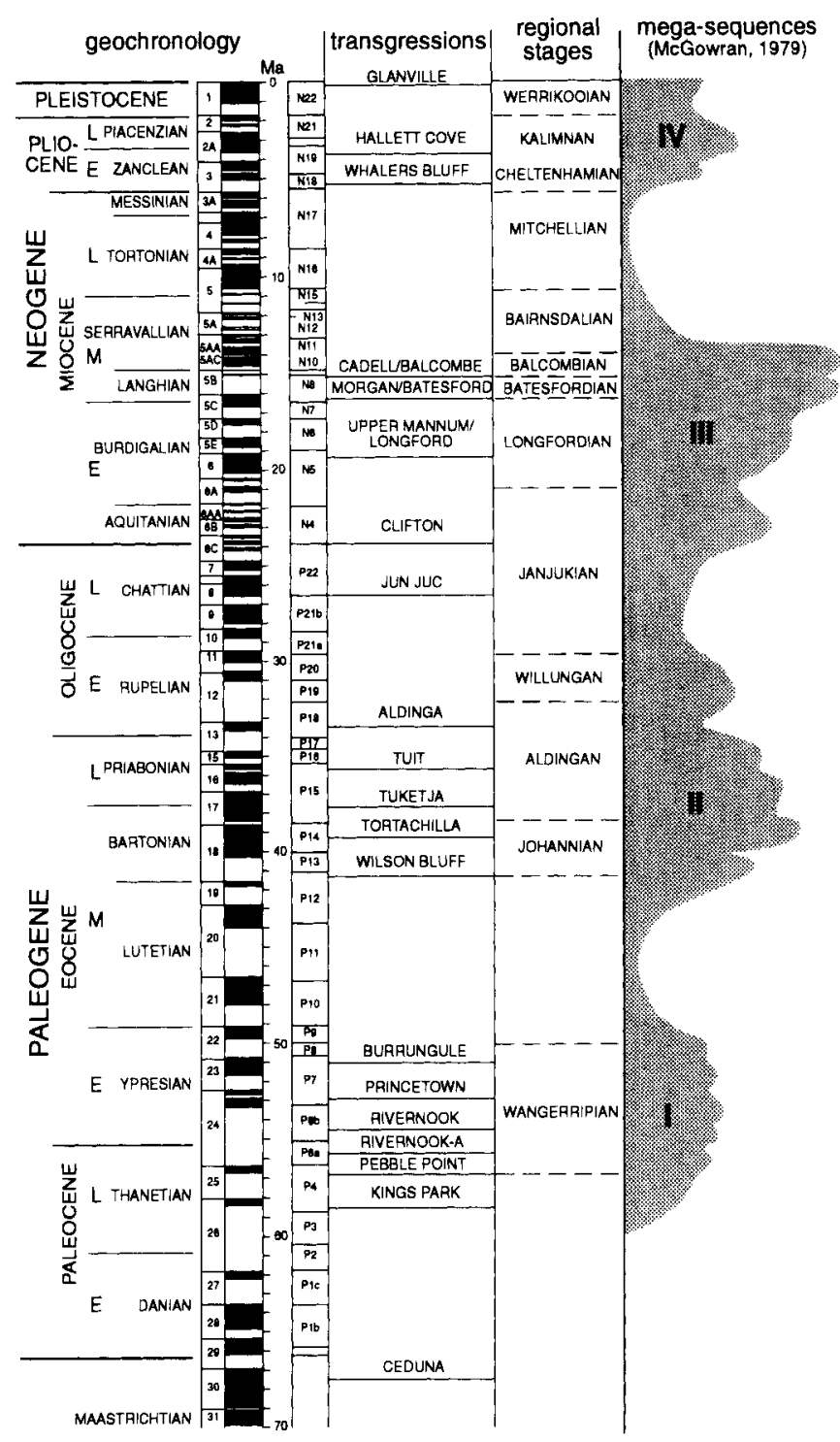

Fig. 2. Local (bio)stratigraphic framework, with standard geochronology and 'Four Megasequences' (of McGowran, 1979) superimposed. The magnitude of their distribution is comparative and is not to scale.

Oligocene, rather than purely Holocene as previously recognized by Loeblich \& Tappan (1987). Similarly, a form referrable to Bronnimannia haliotis (Heron-Allen \& Earland) has been found in the Cadell Marl (early Middle Miocene), the earliest record of that genus from outside North America (Li \& McGowran, 1995). Several small species which appear to be (semi)endemic are illustrated in Plate 1.

Also in Plates 1 and 2 are examples of species with a test of medium size $(200-300 \mu \mathrm{m})$ which are known to be (semi)endemic and sporadically abundant. Together with Angulogerina multicostata Bergquist, Uvigerina sp. (Pl. 1, Figs 14, 15) occurs abundantly in the Blanche Point Formation, a late Eocene sequence from the eastern St 


\begin{tabular}{|c|c|c|c|}
\hline Time Interval & Endemic \& semi-endemic species & Migratory species & Cosmopolitan species \\
\hline Quaternary-Pliocene & $\begin{array}{l}\text { Parredicta porifera } \\
\text { Discorbis dimidiatus } \\
\text { Rosalina australis } \\
\text { Cribrobulimina mixta }\end{array}$ & $\begin{array}{l}\text { Amphistegina lessonii s.l. } \\
\text { Marginopora vertebralis }\end{array}$ & $\begin{array}{l}\text { Elphidium crispum, E. macellum } \\
\text { Cibicides refulgens } \\
\text { C. pseudoungerianus } \\
\text { Heterolepa subhaidingeri } \\
\text { Pullenia quinqueloba } \\
\text { Miniacina miniacea }\end{array}$ \\
\hline middle to late Eocene & $\begin{array}{l}\text { Wadella hamiltonensis } \\
\text { Asterigerinella adelaidensis } \\
\text { Massilina ludbrookae } \\
\text { Maslinella chapmani } \\
\text { Crespinina kingscotensis } \\
\text { Linderina glaessneri } \\
\text { Halkyardia bartrumi } \\
\text { Notorotalia stachei } \\
\text { Karreria spp. } \\
\text { Buccella lotella } \\
\text { Quasibolivinella taylori } \\
\text { Globorosalina spp. }\end{array}$ & $\begin{array}{l}\text { Asterucyclina sp. } \\
\text { Operculina sp. }\end{array}$ & $\begin{array}{l}\text { Anomalinoides umbonata } \\
\text { Planulina biconcava } \\
\text { Patellina corrugata } \\
\text { Spirillina decorata } \\
\text { Uvigerina alabamensis } \\
\text { Sphaeroidina bulloides } \\
\text { Sphaeroidina variabilis } \\
\text { Lenticulina gyroscalprum } \\
\text { Glandulina symmetrica } \\
\text { Triloculina tricarinata }\end{array}$ \\
\hline
\end{tabular}

Table 1. Examples of benthic foraminifera found in southern Australia. Refer to Fig. 6 for the range of some of these species.

Vincent Basin (McGowran \& Beecroft, 1986a; McGowran et al., 1992). Kolesnikovella australis (Pl. 1, Fig. 18) is common in the southern Australia-New Zealand region from middle Eocene to Miocene, whereas Sigmoidella chapmani (P1. 1, Fig. 19) occurs only from the Gippsland Basin and northeastern Tasmania in the early Miocene. The most important semi-endemic assemblage is perhaps the trochospiral to planispiral Notorotalia group, including Notorotalia, Cribrorotalia, Discorotalia and Parrellina and which ranges from the middle Eocene to Recent. The discoid Sherbornina also appears to be semi-endemic, with a range from (late Palaeocene?) middle Eocene to middle Miocene, though its sporadic occurrence in areas beyond Australia-New Zealand has been reported. From Tasmania and Western Australia, Quilty (1980, 1981) identified about 20 new, mainly (semi)endemic, species.

Taxa with a larger test are comparatively well known because many of them are not only common but stratigraphically significant (Pl. 2). Glaessner \& Wade (1959) clarified the taxonomy of several species related to Victoriella conoidea. Although it was first described from New Guined, $V$. conoidea (=Carpenteria proteiformis var. plecte Chapman) occurs frequently in the southern Australian Oligocene. The discovery by Glaessner \& Wade
(1959) and Lindsay (1985) that the last appearance of $V$ conoidea approximates the Oligocene/Miocene boundary is confirmed here. On the other hand, Wadella hamiltonensis (Pl. 2, Fig. 12) represents one of the endemics sensu stricto in the later middle to late Eocene. It is probable that $W$. hamiltoensis gave rise to $V$. conoidea, and the latter subsequently acquired a wider distribution. Both the tubulated $V$. conoidea and the smooth $W$. hamiltonensis are high trochospiral, having a test as large as $2 \times 1.5 \mathrm{~mm}$. Some flattened to conical forms flourished locally also in the later part of the Eocene, particularly Linderina glaessneri (PI. 2, Fig. 13), Crespinina kingscotensis and Halkyardia bartrumi (Pl. 2, Figs 14, 15).

Much remains to be done to systematically record the southern Australian foraminifera. With the imperfect data available to date we estimate that at least 300 of about $800-1000$ species reported from the Cenozoic in southern Australia, or about $30 \%$ of total benthic fauna, are endemic or semi-endemic (see Appendix). This figure is higher than the record of Buzas \& Culver (1989) who found 175 from over 800 reported species (c. $22 \%$ ) endemic to the Atlantic continental margin of North America. The majority of their endemic species, however, appeared since the Pleistocene. The opposite is true here, as discussed below. 


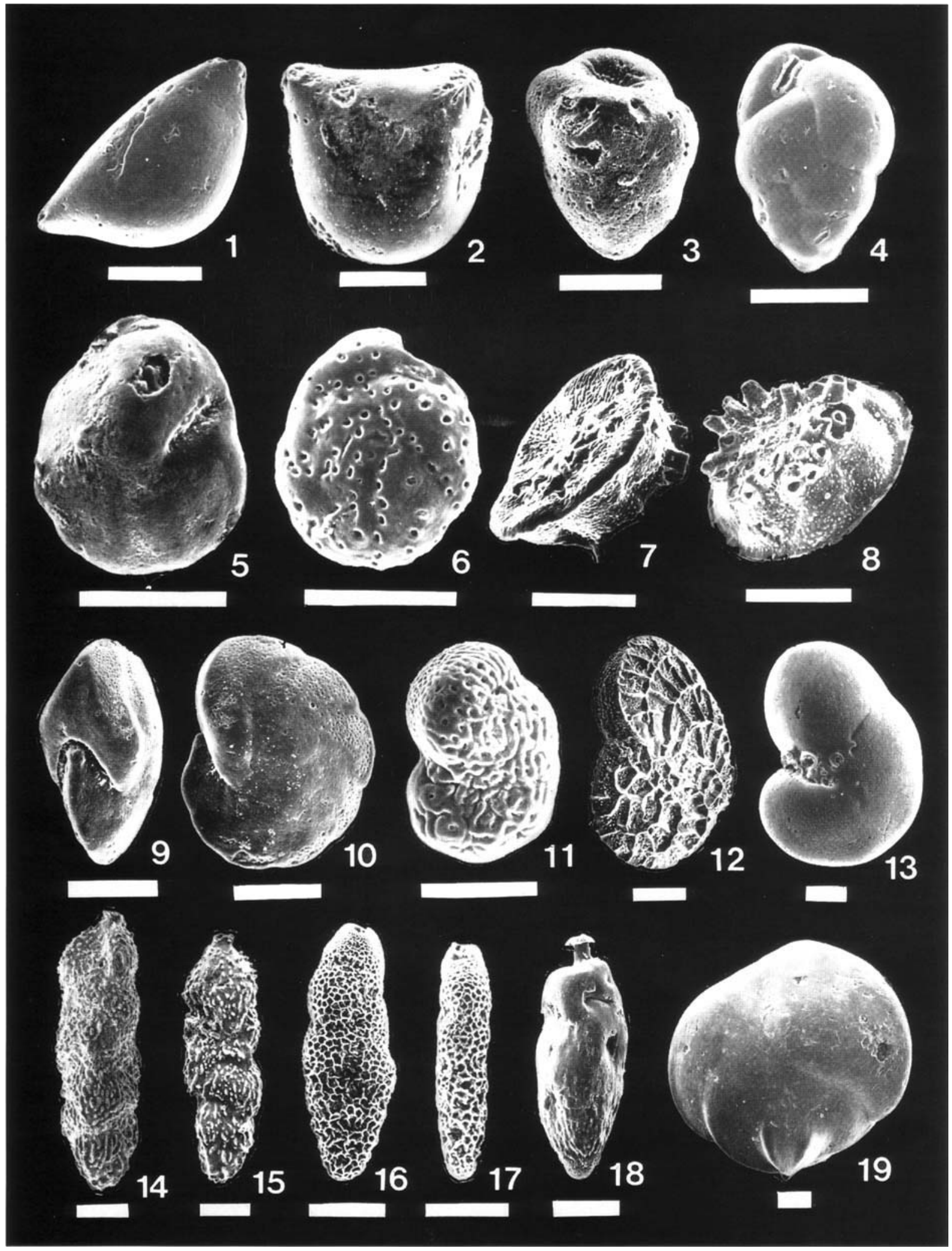

Plate 1 


\section{DISTRIBUTIONAL PATTERNS}

The ranges of selected endemic species (sensu lato) are shown in Fig. 3, against conventional chronobiostratigraphy. These species are concentrated in four post-Palaeocene sequences: later Eocene, Oligocene, Miocene and Pliocene to Quaternary.

Foraminifera incorporated in sediments of Mega-sequence I (mainly Wangerripian in Fig. 2) are the only group for which specific comments about endemism have been made previously (Berggren et al., 1975). It was a time of cosmopolitan faunas and little biogeographic or climatic differentiation, with two major benthic assemblages 'Midway' and 'Velasco' types, which appear to be controlled by water depth. Australian studies (Parr, 1938: McGowran, 1964 et seq.) have defined some of the most important species (including both benthic and planktonic species) and Berggren et al. (1975) have discussed the possible synonymy of the various benthic species. The Australian faunas are generally 'Midway type'. The main exception to cosmopolitanism in the benthic assemblages in southern Australia relates to the apparently extra-Tethyan, possibly cooler water, distribution of the aragonitic Robertinacea (McGowran, 1965).

\section{Later middle to late Eocene}

Compared to the patchy Palaeocene record, later Middle to Late Eocene deposits rich in foraminifera are much more widespread across the vast coast of southern Australia (Quilty, 1969, 1981; McGowran, 1979, 1990, 1991a, 1992). It is from these sequences that many endemic species have been recovered and are discussed here. Apart from Notorotalia spp. (PI. 2), Maslinella chapmani (PI. 2, Figs 7 , 8 ) and Wadella hamiltonensis were also widespread. Most of these species were confined to the 40-34 Ma interval, though Crespinina kingscotensis and some Notorotalia ranged into more recent times. Forms with a large test, such as Asterocyclina, Linderina and Halkyardia, occurred only once or twice, exemplifying migrations from adjacent warmer waters, i.e. from western and eastern Australia. In the Nanarup Limestone and equivalents, for example, Cockbain (1967, 1978) and Quilty (1981) found many well-preserved specimens of Asterocyclina, Linderina, Halkyardia, Operculina, as well as many small endemics including Globorosalina, Pseudopolymorphina carteri and the semi-endemic Quasibolivinella.

The later Eocene sequences are well exposed in Maslin Bay on the eastern coast of St Vincent Gulf. In the silica-rich Blanche Point Formation, two benthic groups (cibicidids and uvigerinids) are predominant and their abundances alternate with each other through the section (McGowran \& Beecroft, 1986a). Apart from the well-known or ecologically significant (semi)endemic species like Cibicidoides perforatus and Uvigerina sp., some smaller forms also appear to have been restricted to the region, including Suratkina sp. (PI. 1, Figs 5,6) and ?Discorotalia sp. (Pl. 1, Fig. 11).

\section{Oligocene}

The earliest Oligocene saw re-occurrence of some of the Late Eocene species. This however was immediately followed, in the later early Oligocene, by reduced endemism, with few new species being introduced. Long-ranging (semi)endemic species found in the early Oligocene include Crespinina kingscotensis and Sherbornina atkinsoni (Fig. 3).

Following a mid Oligocene regression during the lower Janjukian (Fig. 2) a new transgression commenced in the late Oligocene, equating with the upper Janjukian. This transgression brought with it the successive occurrence of the (semi)endemic Discorotalia (PI. 1, Fig. 12) and migratory Amphistegina, as well as the re-introduction of the Notorotalia group in several basins. Figure 4 profiles the abundance of some important species groups from a borehole in the Gambier Embayment, Otway Basin, showing the rise of the elphidiids (mainly Notorotalia spp. and Parrellina spp.) which subsequently outnumbered others in the vicinity of the early/late Oligocene boundary.

The immigration of Amphistegina in the late Oligocene is significant in terms of environmental changes in the region (Lindsay, 1985). At least 5 carbonate hard bands with Amphistegina exist within the Port Vincent Limestone (Oligocene to early Miocene) on the eastern coast of Yorke Peninsula (Shubber et al., 1994). The southern Australian record of this taxon clearly indicates: (i) it had immigrated from the (sub)tropics where it first appeared in the Eocene, and (ii) during the late Oligocene and early Miocene, the influence of (sub)tropical climate or watermass on the continental margin of southern Australia was periodic.

Victoriella conoidea is another migratory species which became stratigraphically important in the later Oligocene and subsequently survived through the Oligocene/Miocene transition. Together with several endemic species; however, it became extinct in the early part of the early Miocene.

\section{Explanation of Plate 1}

Examples of small (semi)endemic taxa. Scale bar $=100 \mu \mathrm{m}$. Fig. 1. Duoforisa rima Li \& McGowran, late Oligocene, Gippsland Basin. Fig. 2. Duoforisa diducta Li \& McGowran, early Miocene, Gippsland Basin. Fig. 3. Angulodiscorbis ludbrookae Quilty, middle Miocene, Gippsland Basin. Fig. 4. Turrilina browni (Finlay), early Miocene, Gippsland Basin. Figs 5, 6. Suratkina sp., single specimen, late Eocene. St Vincent Basin. Figs 7, 8. Colonimilesia sp., single specimen, early Oligocene, Murray Basin. Figs 9, 10. Nonion cassidulinoides Hornibrook, early Miocene, Gippsland Basin. Fig. 11. ?Discorotalia sp., late Eocene, St Vincent Basin. Fig. 12. Discorotalia tenuitissima (Karrer), early Miocene, Gippsland Basin. Fig. 13. Parredicta porifera (Parr), Recent, Lacepede Shelf, Figs 14, 15. Uvigerina sp., two specimens, late Eocene, St Vincent Basin. Fig: 16, 17. Rectobolivina maoriella Finlay, early Miocene, Gippsland Basin. Fig. 18. Kolesnikovella australis (Heron-Allen \& Earland), early Miocene, Gippsland Basin. Fig. 19. Sigmoidella chapmani (Heron-Allen \& Earland), early Miocene, Gippsland Basin. 


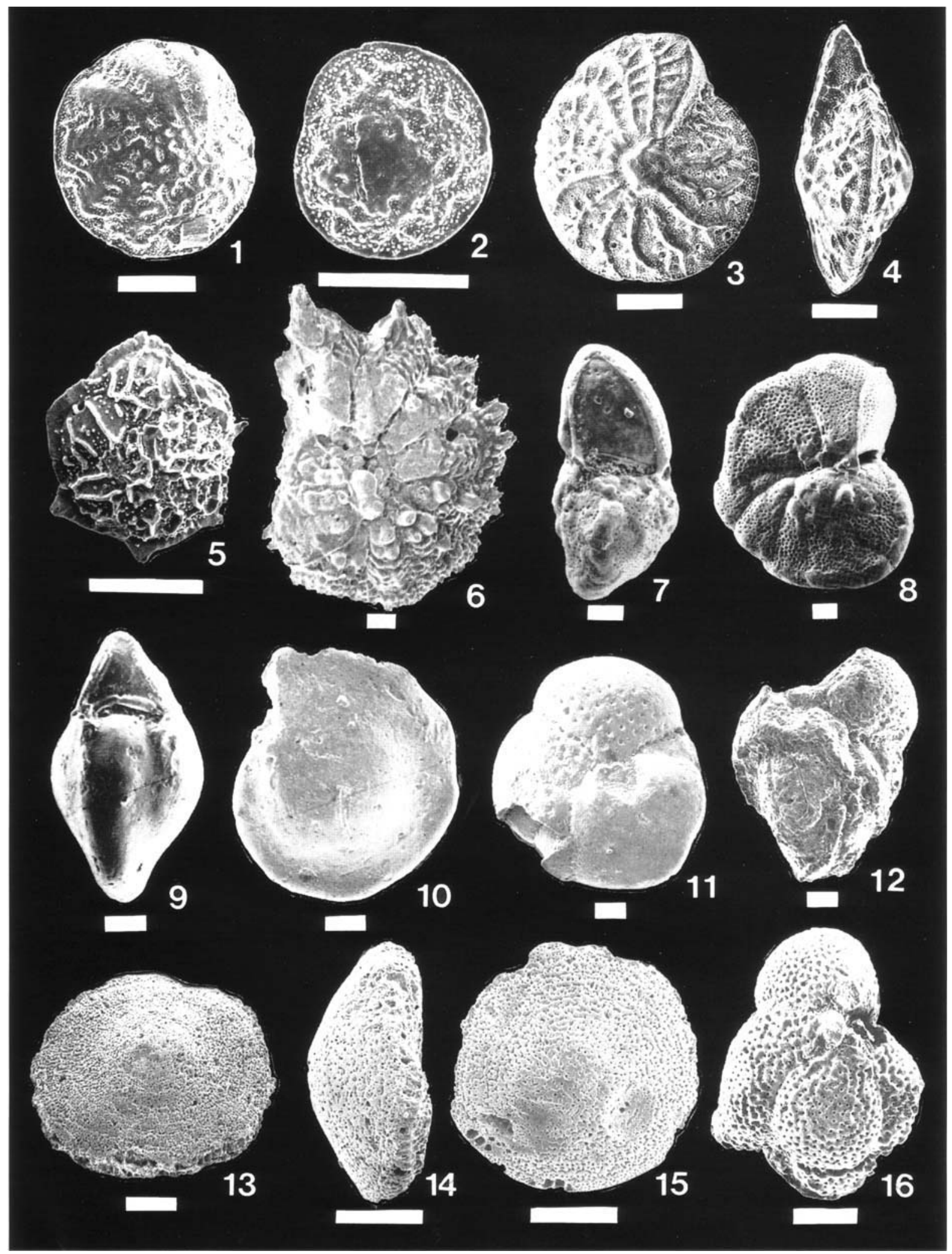




\section{Miocene}

The early Miocene was characterized by the commencement of the most extensive inundation of the southern margin, climaxing in the Batesordian-Balcombian at the early/middle Miocene boundary. It was accompanied by a new phase of endemism and, most importantly, an intensified migration of the (sub)tropical fauna. Among numerous endemic and semi-endemic species, Tenisonina tasmaniae, Crespinella parri, C. umbonifera (Pl. 2, Figs 9, 10) and Sherbornina cuneimarginata occurred strictly in the early Miocene. Parrellina craticulatiformis, Pararotalia verriculata (PI. 2, Fig. 6) and Hofkerina semiornata also made their appearances in this interval and ranged into the middle Miocene. Many small, long-ranging species also occur, such as Angulodiscorbis ludbrookae (PI. 1, Fig. 3), Turrilina browni (Pl. 1, Fig. 4), Rectobolivina maoriella (Pl. 1. Figs 16, 17) and Nonion cassidulinoides (Pl. 1, Figs. 9, 10). Apart from Amphistegina from the larger benthic group, Operculina, Marginopora, Austrotrillina, Lepidocyclina and Cycloclypeus invaded southern Australian waters from the tropics and subtropics. This migration reached its maximum close to the carly/middle Miocene boundary, at the Miocene climatic optimum (McGowran \& Li, 1994). With Lepidocyclina reaching northwestern Tasmania, we suggest that the flow of the Leeuwin Current was the probable cause of this migration. All migratory species retreated or became extinct at about $14 \mathrm{Ma}$ in the later middle Miocene (Zone N10), with few sporadic records from Zones N15-N17.

The late (and part of the middle) Miocene are poorly represented in southern Australia (Fig.2), because of a widespread unconformity due probably to nondeposition during an interval of lower sea level (Quilty, 1977b; McGowran, 1979; Haq et al., 1987; Quilty \& Telfer, 1994). Accordingly, few endemic species have been reported from the region and a low level of endemism is assumed.

\section{Pliocene to Quaternary}

Following the major later Miocene regression, the Pliocene saw a rise in sea-level, commencing in the Cheltenhamian of the Early Pliocene and reaching a peak in the Kalimnan of the late Pliocene. The early Pliocene Cheltenhamian coincided with the 'warm, wet phase' of Truswell (1990) which seems to reflect a globally warmer interval of high sea-level and more humid conditions onshore in Australia. The Kalimnan appears, in southern Australia, to be more widespread than the Cheltenhamian, apparently the reverse of the global situation compiled by Haq et al. (1987), which indicates that early Pliocene sea-level was higher than during the late Pliocene.

In the late Pliocene, a brief reappearance of the (sub)tropical Amphistegina and Marginopora (Fig. 3) probably indicates a short-lived warming event. Typical forms that evolved during this period include Discorbis dimidiatus s.l. which, in both Australia and New Zealand, survived through the Quaternary and is a significant component of today's shallow-water faunas (Li et al., 1996).

The Pliocene-Quaternary foraminifera are very modern in both characters and composition. During the Quaternary, invasion by warm water species was limited to the Pleistocene interglacial intervals. No (sub)tropical species nor significant endemism has been found in the modern fauna, although several taxa such as Parredicta porifera ( $\mathrm{Pl}$. 1, Fig. 13), Glabratella australensis and Cribrobulimina mixta appear to be locally common (Table 1; Fig. 6). Species of Notorotalia and Parrellina survived the Oligocene to Pliocene, and became abundant in the Quaternary .

Most of the recent endemic and semi-endemic species occur in rather shallow waters, with a maximum depth of about $250 \mathrm{~m}$ (mostly $<150 \mathrm{~m}$ ). As an example, Parredicta porifera lives between $50-180 \mathrm{~m}$, and Rosalina australis in depths $<100 \mathrm{~m}$ on the Lacepede Shelf (see Fig. 6). This suggests that coastal waters influence the speciation and colonization of these endemic species. Their distribution, however, may have been superimposed on a latitudinal effect, because they are mainly distributed over the temperate belt along all southern mid-latitude, continental margins. For example, Notorotalia clathrata (PI. 2, Figs 3, 4) occurs in New Zealand (Vella, 1957) and South America (Boltovskoy et al., 1980), as well as southern Australia.

\section{ENDEMISM VIS-À-VIS TRANSGRESSIONS: A POSITIVE RELATIONSHIP?}

Cenozoic benthic foraminifera, either endemic to southern Australia or southern mid-latitude regions or immigrants from the (sub)tropics, occur in southern Australia mainly in four time intervals: middle to late Eocene, Oligocene, early to middle Miocene and Pliocene-Quaternary. A period of strong endemism in the later middle to late Eocene was concomitant with the migration into the region of several warm-water species. The Oligocene was transitional between this strong endemism and the more obvious (sub)tropical migration which happened subsequently in the Miocene. Typical (sub)tropical species characterized the later early to early middle Miocene benthic fauna. From Pliocene to Quaternary, a few endemic and semi-endemic

\section{Explanation of Plate 2}

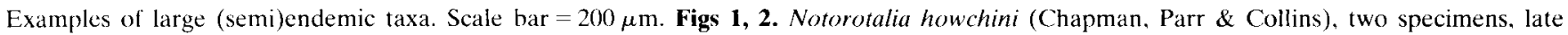

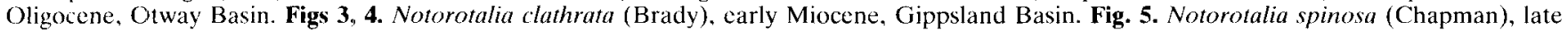

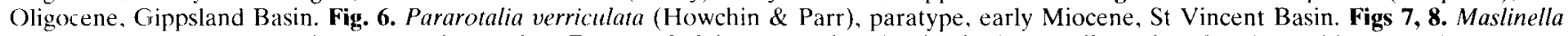

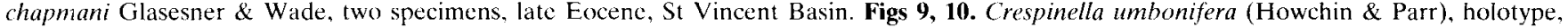

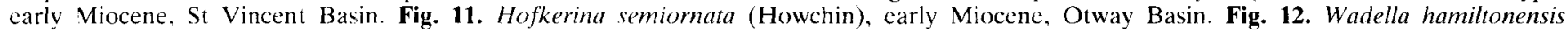

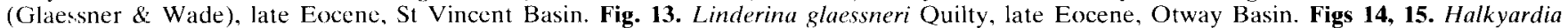
bartrumi Parr, two specimens, late Eocene. Otway Basin. Fig. 16. Wadella globiformis (Chapman), early Miocene, Gippsland Basin. 


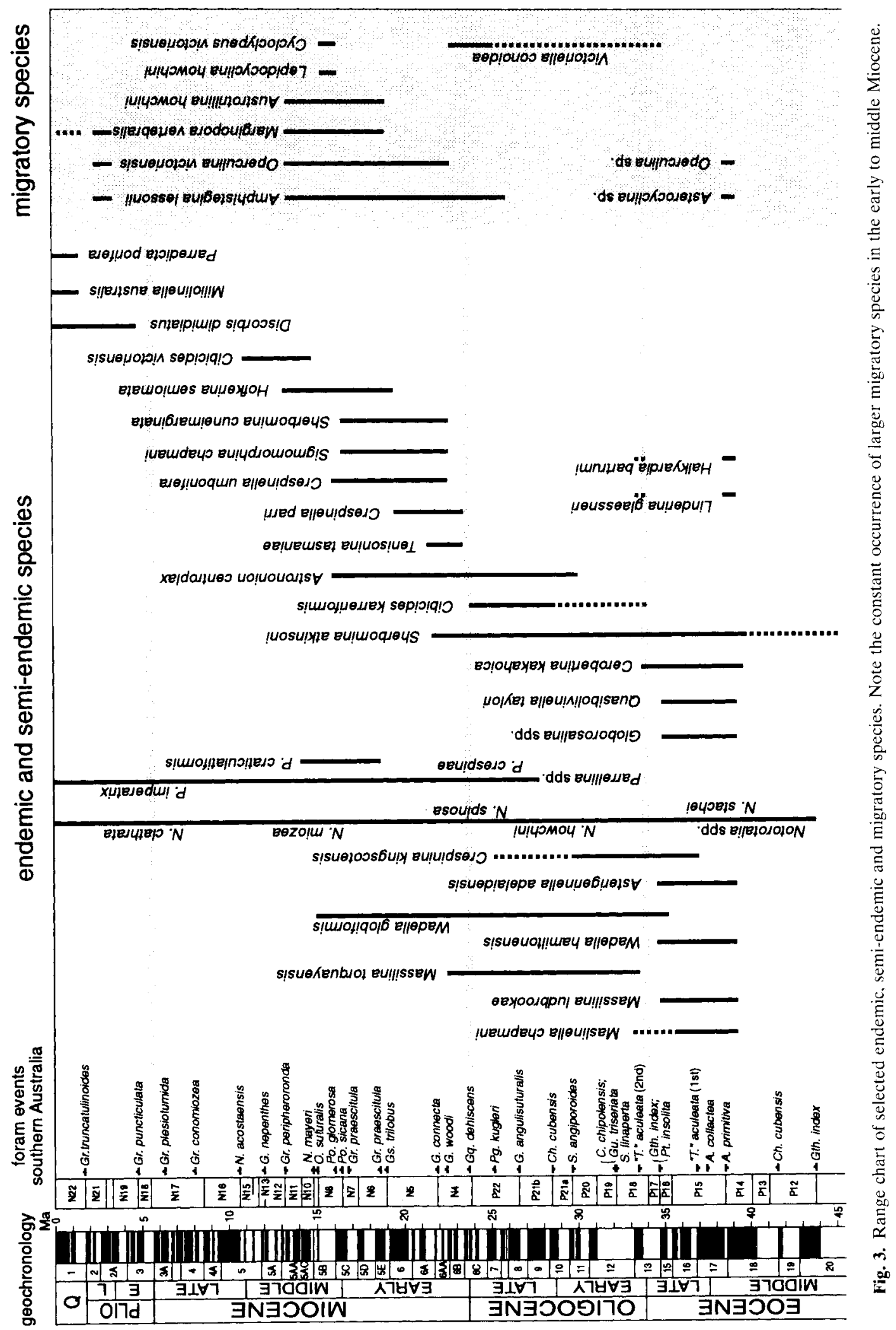


SADME Bore OB2, Robe, Gambier Embayment

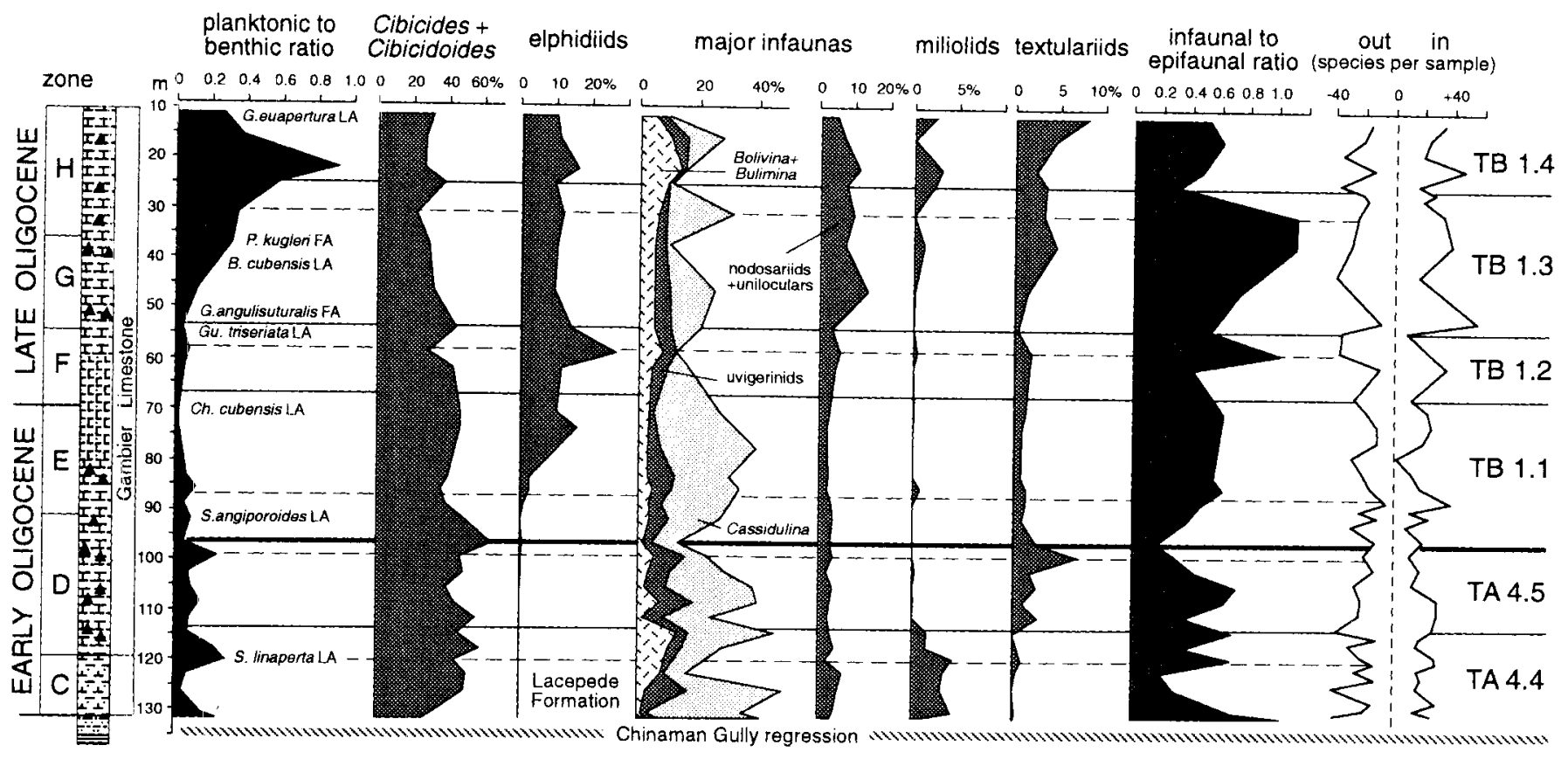

Fig. 4. Faunal profile from a borehole in Otway Basin. The appearance and increase of the elphidiids (mainly Notorotalia and Parrellina) in the middle part of the section coincides with a warming and transgression towards the late Oligocene. Planktonic datums (FA--first appearance; LA--last appearance) were used for biostratigraphy. TA 4.4 to TB 1.4 are third-order sequences by correlation.

forms occur, and only on occasions did warm-water species (for example species of Amphistegina and Operculina) migrate into the region.

Finding these foraminiferid assemblages prompts the following questions: What were the characteristics of coastal waters which bathed the region during these periods? Why and in what way did their properties and behaviour change through time? How did the endemic and migratory species respond to such changes?

The passive continental margin in southern Australia in the Cenozoic was not subject to significant marine deposition until the late Palaeocene. The late Palaeocenecarly Eocene deposits represent the first of four Cenozoic mega-sequences which contain local signals of global warming and high sea-level (Quilty, 1977b; McGowran, 1979, 1991a. b). Unfortunately, these sequences occurred only in a linited area in the Otway Basin (Fig. 1), making investigations of the lateral distribution of endemic species (if any) difficult. Although similar sequences have been reported from the Perth Basin, the faunas there show a stronger infuence by subtropical water masses. The later middle Eocene to middle Miocene deposits are widespread and outcrop well, hence are more relevant to our analysis.

Deposited at about $40 \mathrm{Ma}$ in the later middle Eocene were the Wilson Bluff and Tortachilla Formations. Together with subsequent late Eocene sediments, these rock units constitute 'Sequence Two' (of McGowran, 1979) and indicate a major marine transgression. The late Oligocene to Miocene 'Sequence Three' was a similar but represents a stronger transgression, peaking with the deposition of the Morgan and Batesford-Balcombe Limestones. Similarly, the Pliocene and Quaternary experienced the last major transgression - 'Sequence Four'. Sequence Two and Three each spanned a time of about $10^{7}$ years respectively, at the same time-scales of second-order eustatic cycles. Equivalent sequences have been found, either as outcrops or from subsurface, from Western Australia (Quilty, 1977b) and Tasmania (Quilty, 1972, 1980). Based on this correlation we note and discuss the relationship between transgressions and foraminiferal endemism and migration. Sequence Four (Pliocene-Quaternary) is not yet complete and thus represents a shorter time interval so far.

It has been suggested that transgressions, commonly associated with climatic warming and a high sea-level, triggered speciation and colonization of the newly established ecosystem in various regions (McGowran, 1979, 1986; Kauffman, 1987; McGhee et al., 1991; Olsson \& Usmani, 1992). Transgressions altered or even destroyed old regimes and, at the same time, created many new microhabitats. The availability of microhabitats was enhanced as the sea water invaded flattened shelves and beyond. Only under this circumstance did the development of endemic species, as well as the migration of (sub)tropical and cosmopolitan taxa, become possible. We suggest that each large transgression in the Cenozoic caused a major reorganization of benthic assemblages. On the other hand, the subdued endemism and immigration in the early to mid-Oligocene coincides with a time of cooling and 


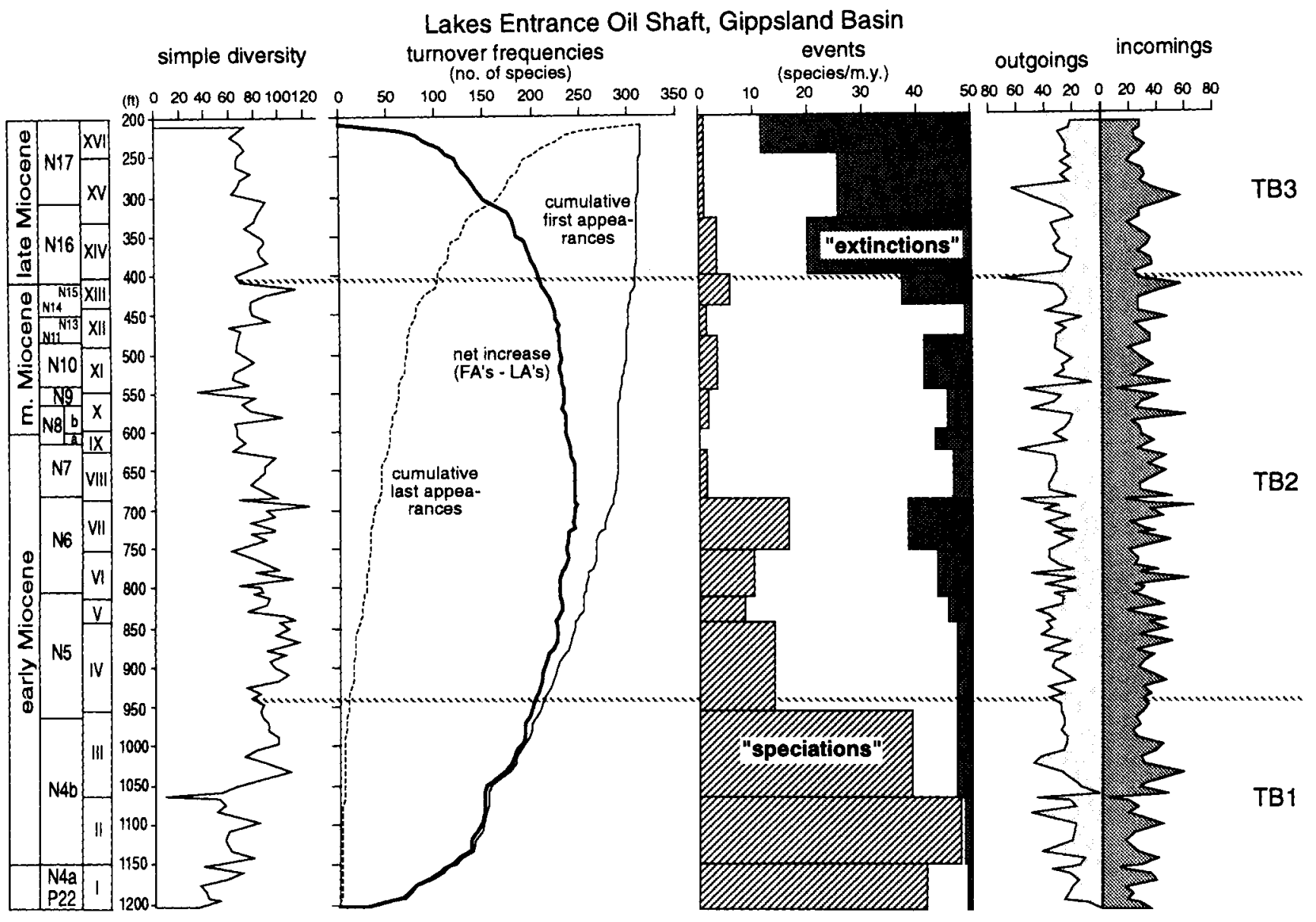

Fig. 5. Faunal variations in the Lakes Entrance Oil Shaft, Gippsland Basin (Li \& McGowran, 1995a). From left to right, they are: benthic species diversity, turnover, rate of first and last appearances by planktonic assemblages (I to XVI), and numbers of repeatedly outgoing and incoming species in successive samples. Speciations appear to be concentrated in the early part and extinctions in the later part of the section. They are of course exaggerated by the artefacts of the data constrained by sampling: a figure of 40-50 speciations (or extinctions) per million years is ridiculously high. But the 'speciations' high in the transgressive phase of the supersequence TB2, with about 10 species per million years, is reasonable.

regression in southern Australia (McGowran, 1979; McGowran \& Beecroft, 1986a, b; Moss \& McGowran, 1993) and elsewhere (Haq et al., 1987).

Sediments from the Lakes Entrance Oil Shaft in the Gippsland Basin span the later Oligocene and almost the entire Miocene (McGowran \& Li, 1993). A detailed study of the section by Li \& McGowran (1996) identified over 400 benthic species, of which about $30 \%$ are endemic. Many, if not all, have a coming-going-recoming pattern at least once, in response to environmental changes (or facies changes) during the Oligocene-Miocene (Fig. 5). Within supersequence TB2 (N5-N15) of Haq et al., (1987), 10-15 first appearances were recorded from a single assemblage zone in the early, transgressive phase, compared with $<4$ appearances in the maximum transgressive interval (N7-N9) and in later, regressive system tracts (Fig. 5). We conclude that transgressions created new habitats, so the speciation and migration of benthic foraminifera became possible, and thus probably as their local endemism.

The other side of this argument is that perhaps it was not transgressions but regressions that were the main cause of endemism, because habitats would be much more restricted during the sea-level fall. The concentration of endemic species in widespread transgressive sequences may be due to better preservation. Regressive strata are spatially limited and contain a fossil fauna biased by poor preservation, so endemic species, if any, are not easily identified. We object to this reasoning on the basis that an increased species diversity was associated with transgressions or ingressions, but not with regressions. In southern Australia, a higher diversity would be found when more migratory or endemic species occurred. For example, Notorotalia first appeared in later middle Eocene, and its reappearance, together with many decendants like Discorotalia and Parrellina in Otway and Murray Basins, was in the late Oligocene, all associated with two major transgressions in southern Australia (Fig. 1).

\section{CORRELATION WITH THE SOUTH AMERICAN RECORD}

No study of this type can be complete without comparable analyses from other Southern Hemisphere localities but such 


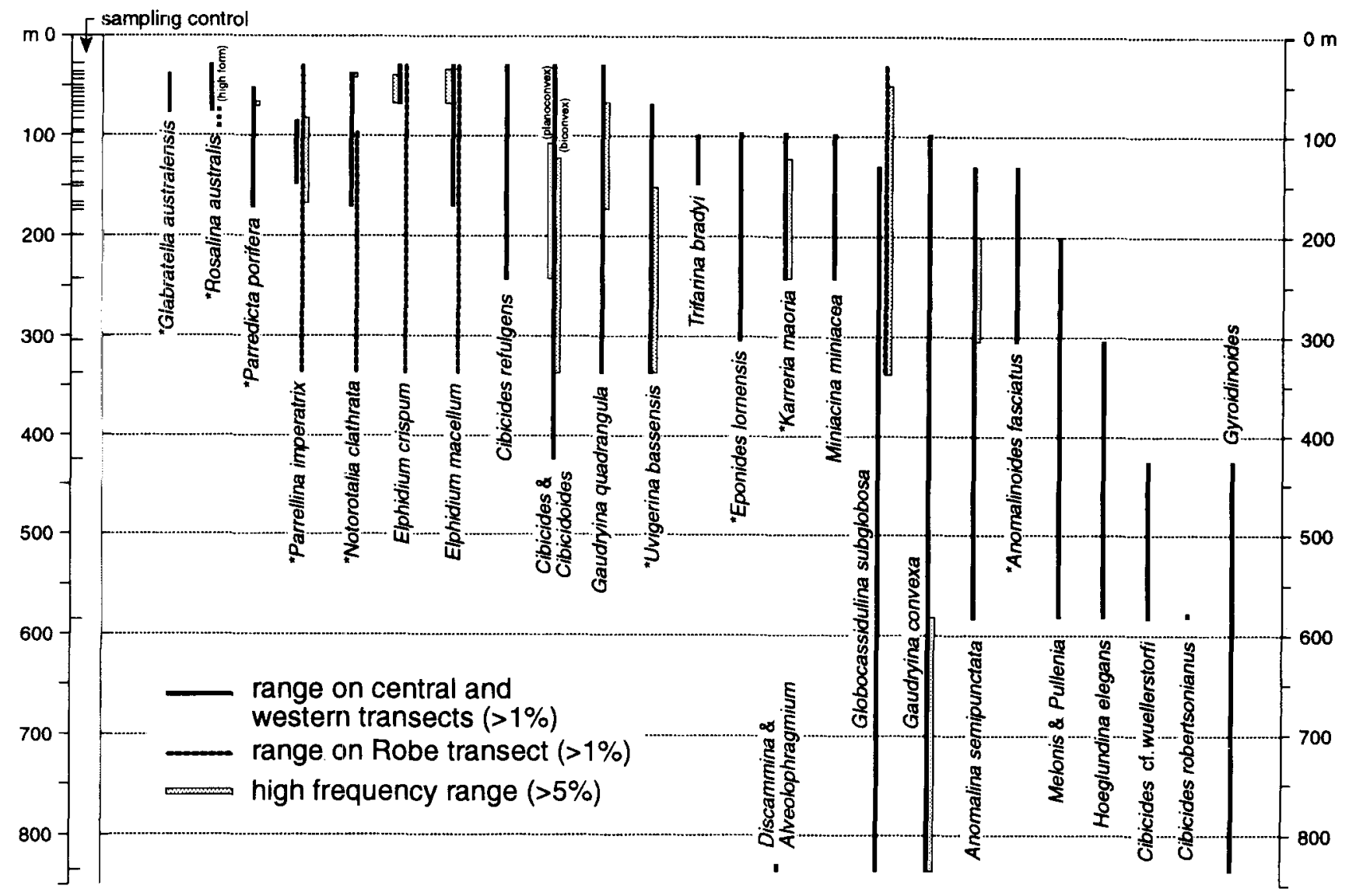

Fig. 6. Depth ranges of selected modern benthic taxa on the Lacepede Shelf (adapted from Li et al., 1996). Note that the endemic species (*) occur mainly in shallow-water sites. Downslope transport is more prevailing on the Robe transect.

analyses are rare and incomplete. No such analysis has been conducted in South Africa but enough is known of South American faunas to justify similar analyses to that performed here. Boltovskoy et al. (1980) have provided a basis for comparison of modern foraminiferal faunas of Australasia and South America. More recently, Malumian (1978, 1989) and Malumian \& Nañez (1988) have commenced the equivalent analysis in Argentina for the Eocene-Miocene, even referring to New Zealand stage terminology and comparing transgression/regression history with the eustatic sea-level curves of Haq et al. (1987). Their results are enough to indicate that the bulk of the forms taken here to be endemic or semi-endemic are unknown from South America although there are some links in the faunas between Australasia and South America. Malumian (pers. comm. 1994, with minor editorial modification for consistency) states 'In Argentina, the general framework is given by transgressions. (1) The Maastrichtian-Danian transgression shows an endemic microfauna in the Maastrichtian, and a cosmopolitan one in the Danian. (2) The middle Eocene transgression has typical genera of the southern hemisphere as Boltovskoyella, Cribrorotalia, and some miliolids, and it seems to be the Cenozoic transgression that has most endemic species. (3) The Late Eocene?-Oligocene transgression has a typical assemblage of Antarctic origin, with dominant agglutinated foraminifera and frequent planktonic taxon Antarcticella. This assemblage reaches the Colorado Basin ( $39^{\circ}$ latitude S). (4) The later Oligocene-middle Miocene transgressions have similar assemblages to that living today in our (Argentine) platform'. Malumian (1990) stated that, for the Middle and Upper Eocene of one section through the Man Aike Formation, 'Nearly half of the species are common or show affinities with those of the middle and upper Eocene of New Zealand'.

It seems that the pattern of transgression/regression in Argentina is similar to that recognized in southern Australia but the features of the endemism are different for each transgression. The Palaeocene, like that of Australia is a 'Midway' type, essentially free of endemism. While the late Eocene-early Oligocene was the time of maximum endemism, similar to the pattern in Australia, the fauna is quite different from that of Australia with strong Antarctic links with many agglutinated forms and the unusual planktonic form Antarcticella. Again, the late Oligocenemiddle Miocene has a lower endemism than the late Eocene-early Oligocene, and the fauna is generally similar to that existing today.

The evolution of these foraminiferal faunas is linked to changes in sea-level, ocean temperature and, perhaps, 
salinity. Changes in these parameters are dependent largely on changes in global ice volume which, until about $2.6 \mathrm{Ma}$ ago (late Pliocene) when there is the first reliable evidence for northern hemisphere glaciation, appears to be controlled by events in the Antarctic, themselves influenced very strongly by changes in continental position. Veevers (1984) provides a useful background to the continental changes related to Australian region, but the evolution of Antarctica through the Cenozoic was poorly known until recently (Webb, 199); Kennett \& Barker, 1990; Quilty, 1992). There is a fierce debatc at present about the evolution of Antarctica during the Pliocene (see for example, Webb \& Harwood, 1987; Prentice \& Matthews, 1991). One element of global ice volume change seldom referred to is the effect on salinity. Over the last $2.6 \mathrm{Ma}$, the variation in global ice volume represents approximately $7 \%$ of global ocean volume and salinity varied from 33.8 to $36.4 \%$. Its present average is $34.7 \%$. The impact of this change on marine organisms is unknown.

\section{PALAEOENVIRONMENTAL IMPLICATIONS}

Three generalizations can thus be made:

1. A higher sea-level and warmer-water conditions accompanying transgressions generally intensified endemism and immigration of benthic foraminifera, especially from warmer-water sources.

2. Endemic species are mostly shallow-water inhabitants, with a maximum depth range to shelf edges.

3. Changes in the endemic and semi-endemic communities through time indicate changes in the property and activity of coastal water masses, reflecting regional and global climatic fluctuations.

Though endemic patterns are usually a local phenomenon which may not necessarily characterize all benthic groups, the above generalizations seem to have a broader implication. For this reason, we partially support the notion of Buzas \& Culver $(1984,1991)$ that benthic foraminifera were primarily evolving in variable, perhaps shallow-water, environments. McGhee et al. (1991) argued that shallowwater communities seemed to be more immune to sea-level perturbation than the deeper-water communities. However, the frequency of environmental alternations experienced by marine organisms may be more influential than their magnitude' (McGhee et al., 1991, p.703). Whatever the causes, an increasing species diversity with marine transgressions still holds for benthic foraminifera and many other benthic groups (Rollins et al., 1979).

Southern Australia's provincialism is well illustrated by the molluses. According to Wilson \& Allen (1987), over $90 \%$ of the Tertiary and Recent molluses reported from southern Australia are endemic. Darragh (1985) identified two molluscan provinces for the early Miocene to Pleistocene: the (southwestern) Austral Indo-Pacilic and Southeast Australian Provinces. The distribution pattern of the larger benthic foraminifera Flosculinella and Cycloclypeus in the early middle Miocene may support Darragh's suggestion, as Flosculinella was restricted to the early middle Miocene: $15-16 \mathrm{Ma}$ (Morgan)

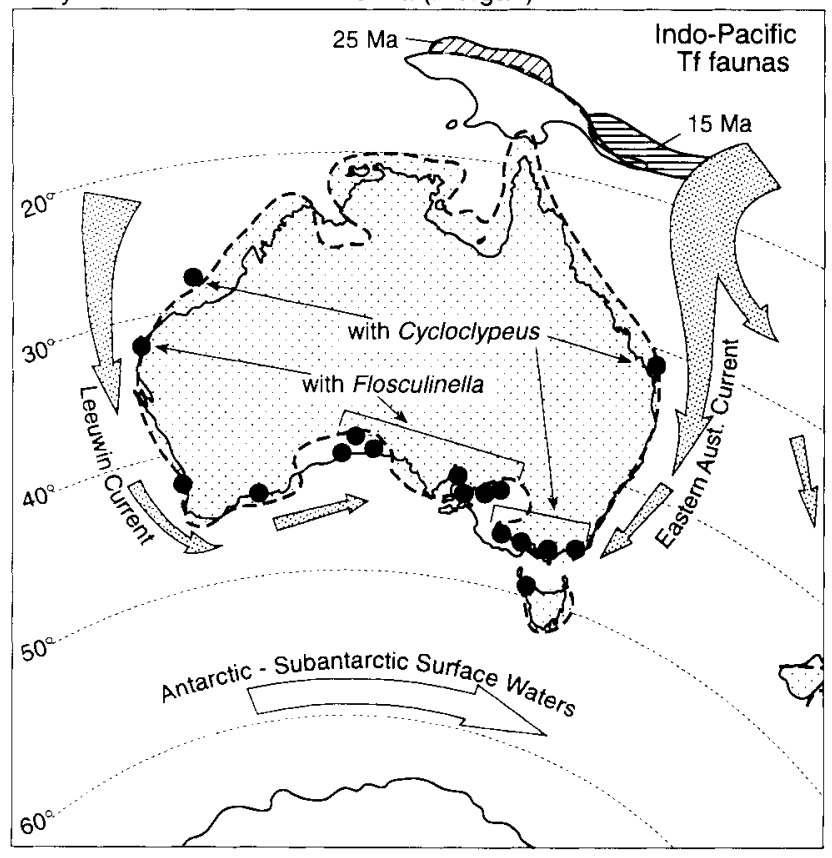

Fig. 7. Distribution of larger (sub)tropical foraminifera in the early middle Miocene. In southern Australia, Cycloclypeus was found in the southeast corner, suggesting the influence of the Eastern Australia Current, while the fauna with Flosculinella from the southwest to central parts may indicate the flow of the Lecuwin Current to this region.

southwest and Cycloclypeus the southeast (Fig. 7). A direct comparison with the molluscs cannot be made in this study, because we are dealing mainly with fossil foraminifera from shelf and deeper-water environments, rather than from beach or estuarine settings. The shallower the waters, the higher the number of endemic species.

Quilty (1981) recognized three foraminiferal subprovinces for the late Eocene of southern Australian and New Zealand. (1) The western margin to the southwestern corner of Western Australia was occupied by the western subprovince with Asterocyclina. (2) Between Western Australia and Victoria was a southern subprovince characterized by many endemic species but without Asterocyclina. (3) The New Zealand subprovince contained Asterocyclina and numerous species endemic to both New Zealand and southern Australia.

As indicated by their distribution data, the extratropical migration of larger foraminifera into southern Australia may reflect the effect of the Leeuwin and Eastern Australian Currents since the Eocene. Not only Asterocyclina, Cycloclypeus and Flosculinella but many endemic species display a disparate distribution between the southwest and southeast parts of the continental margin. Halkyardia bartrumi and Linderina glaessneri occur frequently in the western part of the later Eocene, but have never been recorded from the Gippsland Basin. Among the small benthic forms, Hofkerina semiornata and Parredicta kalimnensis are two early Miocene species with records only 
from the central (Murray Basin) and eastern parts including Tasmania. Almaena gippslandica from later Oligocene and earliest Miocene represents one of the species endemic to the southeast corner, in the Gippsland Basin (Li \& McGowran, 1995). A warmer western margin may have been influenced by the Leeuwin Current, a warm, southerly moving water mass caused probably by differential heat and pressure gradients, as summarized in Cresswell (1991). From middle Miocene onwards, this difference became less distinct as fewer and fewer endemic species occur.

Overall, benthic foraminifera in southern Australia closely resemble those of New Zealand (Hornibrook, 1961: Hornibrook et al., 1989) in species known and community structure, suggesting a regional affinity (Quilty, 1981). The link is obviously through such semi-endemic groups as Notorotalia which occur in southern Australia as well as in New Zealand. Some of these taxa occur also in South America, as discussed above. This pattern is probably due to species dispersal from their planktonic larvae (Valentine \& Jablonski, 1983). It is significant that the dispersal has been strictly confined to such a narrow belt close to the Subtropical Convergence (STC). The STC is the northern boundary of the West Wind Drift, the prevailing current in the Southern Ocean. It has been shown that the STC fluctuated through several degrees of latitude during the Miocene and Quaternary (Loutit, 1981; Almond et al., 1993). Warmer times saw a high sea-level and warm currents invaded southern Australia from the east and west. The opposite might be true during cooler times: a low sea-level, and a northerly advancing West Wind Drift, resulting in a vigorous mixing in waters along the continental margin. The oceanography of this distinctive region could produce a unique biota, as seen in benthic foraminifera. The endemic species thus become by-products of particular environmental settings, different from each other at smaller scales. Some, however, may have developed directly from relic communities, or 'perched faunas' (Johnson, 1974).

\section{SUMMARY AND CONCLUSIONS}

1. Much still remains to be done to catalogue and classify southern Australian foraminifera. Species known only from the region, or endemic species, were well established and occurred together with those cosmopolitan, migratory and semi-endemic taxa since at least the later middle Eocene.

2. A positive relationship seems to have existed between endemism of benthic foraminifera and marine transgressions. Four major endemic phases from middle Eocene to Recent are closely related to four major local transgressions: Wilson Bluff, Aldingan, CliftonLongfordian and Hallett Cove-Glanville. Differences are seen not only between their endemic magnitude but also species composition.

3. The middle and late Eocene represented a period of high endemism, having at least four (semi)endemic genera: Maslinella, Wadella, Crespinina and Quasibolivinella. Larger species migrated from warmer waters from time to time. The Oligocene as a whole had rather low endemism, although the introduction of
Parrellina and immigration of Amphistegina in the late Oligocene are environmentally significant. The endemism was outweighed in the Miocene by migrations into the region of many (sub)tropical larger taxa including Lepidocyclina, Cycloclypeus and Flosculinella. During Pliocene and Quaternary times, there cvolved such new semi-endemic forms as Discorbis dimidiatus and Parredicta porifera, which were accompanied by a few migratory species in warm or interglacial intervals.

4. The modern benthic fauna was built through all of these intervals, with the Miocene and Pliocene being the most important when most modern species started to evolve. Among the (semi-)endemics, Notorotalia is the longest surviving genus, ranging from middle Eocene to Recent.

5. Endemism, and perhaps the evolution of most species, occurred primarily in shallow waters. The properties and activity of coastal waters are believed to be the main factors influencing the evolution and distribution of endemic and other shallow-water species. In southern Australia, the interplay between the warm Leeuwin and Eastern Australian Currents and the cold West Wind Drift resulted in distinct endemism as well as (extratropical) migration of benthic foraminifera. A similarity between faunas from southern Australia, New Zealand and South America is evidence that the prevailing West Wind Drift played a key role.

6. A maturing Southern Ocean, evolving to the modern, can thus be inferred to have started in the Miocene when proportionally decreasing endemism was recorded, reflecting development of a modern style Circumpolar Current. In southern Australia, part of this decreasing endemism was probably triggered by a stronger, though periodic, flow of the Lccuwin Current.

\section{ACKNOWLEDGEMENTS}

This work was supported by an Australian Research Council grant to BMcG and an Australian Postgraduate Research Award to GM. Amanda Beecroft compiled most of the Eocene species. Dr. G. Cresswell is thanked for references on the Leeuwin Current. We are grateful to Drs $\mathrm{N}$. Malumian and A. Concheyro for their prompt responses to requests for information and discussion of our ideas. We thank Dr H. Marchant for his comments on a draft. The manuscript was reviewed by Prof. J.W. Murray and two anonymous referces.

\section{APPENDIX: List of (semi)endemic species}

Alabamina tenuimarginata (Chapman, Parr \& Collins, Pulvinulinella)

Almaena gippslandica Carter

Angulodiscorbis ludbrookae Quilty

Angulogenerina elliptica Dorreen

Angulogenerina esuriens Hornibrook

Anomalina bassensis Parr

Anomalina colligera Chapman \& Parr

Anomalina nonionoides Parr

Anomalina tasmanica Parr 
Anomalinoides fasciatus (Stache, Rotalia)

Anomalinoides macraglabra (Finlay, Anomalina)

Anomalinoides planulata Carter

Anomalinoides procolligera Carter

Articulina victoriana Cushman

Astacolus judyae Hornibrook

Asterigerinella adelaidensis (Howchin, Truncatulina margaritifera var.)

Astrononion centroplax Carter

Astrononion impressum Hornibrook

Astrononion obesum Carter

Astrononion pusillum Hornibrook

Bolivina bassensis Parr

Bolivina lapsus Finlay

Bolivina parri Cushman

Bolivina pukeuriensis Hornibrook

Botellina tasmanica Parr

Bronnimannia haliotis (Heron-Allen \& Earland, Discorbis)

Buccella lotella Hornibrook

Buliminella basicostata Parr

Buliminella missilis Vella

Cassidulina margareta Karrer

Cassidulinoides chapmani Parr

Ceratobulimina clifdenensis Finlay

Ceratobuliminoides bassensis Parr

Cerobertina bartrumi Finlay

Cerobertina kakahoica Finlay

Cibicides amoenus Finlay

Cibicides catillus Finlay

Cibicides cygnorum Carter

Cibicides ihungia Finlay

Cibicides karreriformis Hornjbrook

Cibicides mediocris Finlay

Cibicides pseudoconvexus Parr

Cibicides victoriensis Chapman, Parr \& Collins

Cibicides vortex Dorreen

Cibicidoides deliquatus (Finlay, Cibicides)

Cibicidoides notocenicus (Dorreen, Cibicides)

Cibicidoides perforatus (Karrer, Rotalia)

Cifellia costata (Heron-Allen \& Earland, Chrysalidina)

Cornuspira tasmanica Parr

Cornuspiroides expansus (Chapman, Cornuspira carinata var.)

Crenulostomina banksi Quilty

Crespinella parri Quilty

Crespinella umbonifera (Howchin \& Parr, ?Operculina)

Crespinina kingscotensis Glaessner \& Wade

Cribrobulimina mixta (Parker \& Jones, Valvulina)

Cribrorotalia dorreeni Hornibrook

Cyclammina tasmanica Parr

Dentalina obliquecostata (Stache, Nodosaria)

Dentalina subemaciata Parr

Dentalina translucens Parr

Discorbinella complanata (Sidebottom, Discorbina bertheloti

var.)

Discorbinella scopos (Finlay, Discorbis)

Discorbis balcombensis Chapman, Parr \& Collins

Discorbis dimidiatus (Jones \& Parker, Discorbina)

Discorbis lobatulus Parr
Discorbis umbonifer Parr

Discorbis zealandica (Vella, Pileolina)

Discorotalia tenuissima (Karrer, Polystomella)

Dorothia minima (Karrer, Textularia)

Dorothia pusilla Parr

Duoforisa diducta Li \& McGowran

Duoforisa rima Li \& McGowran

Dyocibicides primitiva Vella

Eggerella ihungia Finlay

Eggerella subconica Parr

Ehrenbergina marwicki Finlay

Elphidium chapmani Cushman

Elphidium pseudoinflatum Cushman

Epistominella cassidulinoides Hornibrook

Epistominella iota Hornibrook

Epistominella macgowrani Quilty

Epistominella pusillus (Parr, Eponides)

Eponides lornensis Finlay

Gaudryina convexa (Karrer, Textularia)

Gaudryina crespinae Cushman

Gavelinopsis pukeuriensis Hornibrook

Glabratella australensis (Heron-Allen \& Earland, Discorbis)

Glabratella crassa Dorreen

Globocassidulina pseudocrassa (Hornibrook, Cassidulina)

Globorosalina scabricula (Chapman, Pulvinulina)

Globorosalina westraliensis Quilty

Gyroidina zelandica Finlay

Heronallenia laevis Parr

Heronallenia parri Carter

Heterolepa brevoralis (Carter, Cibicides)

Heterolepa novozelandica (Karrer, Rotalia)

Heterolepa opacus (Carter, Cibicides)

Heterolepa subhaidingeri (Parr, Cibicides)

Hofkerina semiornata (Howchin, Pulvinulina)

Karreria maoria (Finlay, Vagocibicides)

Kolesnikovella australis (Heron-Allen \& Earland, Uvigerina (anariensis var.)

Lagena tasmaniae Quilty

Lagena tenuistriata Stache

Lamarckina novozealandica Dorreen

Lenticulina altifrons Parr

Lenticulina australis Parr

Lenticulina callifera (Stache, Cristellaria)

Lenticulina foliata (Stache, Robulina)

Lenticulina gyroscalpra (Stache, Cristellaria)

Lenticulina tasmanica Parr

Linderina glaessneri Quilty

Loxostomum pakaurangiensis Hornibrook

Marginulina perobesa Parr

Marginulinopsis allani (Finlay, Marginulina)

Marginulinopsis hydropica Hornibrook

Maslinella chapmani Glaessner \& Wade

Massilina ammophila (Parr, Quinqueloculina)

Massilina ludbrookae Lindsay

Massilina torquayensis (Chapman, Spiroloculina)

Nonion cassidulinoides Hornibrook

Nonionella zenitens Finlay

Notorotalia howchini (Chapman, Parr \& Collins, Rotalia)

Notorotalia powelli Finlay 
Notorotalia spinosa (Chapman, Rotalia clathrata var.)

Notorotalia stachei Finlay

Operculina victoriensis Chapman \& Parr

Ophthalmidium circularis (Chapman, Spiroloculina dorsata

var.)

Pararotalia verriculata (Howchin \& Parr, Rotalia)

Parredicta kalimnensis (Parr, Planulina)

Parredicta porifera (Parr, Valvulineria)

Parrellina craticulatiformis Wade

Parrellina crespinae (Cushman, Elphidium)

Parrellina imperatrix (Brady, Polystomella)

Pelosinella bicaudata Parr

Planularia australis Chapman

Planulina papillata (Chapman, Parr \& Collins, Discorbis bertheloti var.)

Planulina planoconcava Chapman, Parr \& Collins

Plectofrondicularia parri Finlay

Psammophas tasmanica Parr

Pseudononion victoriense (Cushman, Nonion)

Pseudopolymorphina carteri Quilty

Pyrgo cuneana Karrer

Pyrgo subglobulus Parr

Quasibolivinella taylori Quilty

Quinqueloculina venusta Karrer

Rectobolivina maoriella Finlay

Rectobolivina parvula Hornibrook

Reophax brevis Parr

Reussella attenuata Hornibrook

Reussella ensiformis (Chapman, Verneuilina)

Robertina tasmanica Parr

Rosalina australis (Parr, Discorbis)

Sherbornina atkinsoni Chapman

Sherbornina cuneimarginata Wade

Sigmoidella chapmani (Heron-Allen \& Earland,

Polymorphina)

Sigmoilina sabulosa Parr

Sigmomorphina subregularis Howchin \& Parr

Siphoglobulina siphonifera Parr

Siphonina australis Cushman

Siphotextulara obesa Parr

Siphotextularia awamoana Finlay

Spirillina pectinimarginata Chapman, Parr \& Collins

Spirillina unilatera Chapman

Suratkina australiensis (Chapman, Parr \& Collins, Discorbis iuberculata var.)

Suratkina shauni (Quilty, Epistominella)

Tenisonina tasmaniac Quilty

Textularia australis Parr

Textularia hayi Karrer

Textularia semicarinata Hornibrook

Tholosina spiculifera Parr

Trifarina ototara (Hornibrook, Angulogenerina)

Trifarina parva Hornibrook

Triloculina lamellidens Parr

Triloculina striatula Parr

Tritaxia victoriensis (Cushman, Clavulinoides szaboi var.)

Trochammina sorosa Parr

Trochammina spiculolega Parr

Trochammina tasmanica Parr
Turrilina browni (Finlay, Buliminella)

Turrispirillina depressa Parr

Uvigerina bassensis Parr

Uvigerina bortotara costata Dorreen

Uvigerina miozea Finlay

Vaginulina vagina (Stache, Dentalina)

Vaginulinopsis acanthonucleus Carter

Vaginulinopsis procelata Parr

Valvulineria polita Parr

Valvulineria trinucleata Carter

Virgulina rotundata Parr

Wadella hamiltonensis (Glaessner \& Wade, Carpenteria)

Wadella globiformis (Chapman, Carpenteria)

\section{Manuscript received February 1995 Manuscript accepted May 1995}

\section{REFERENCES}

Almond, D., McGowran, B. \& Li, Q. 1993. Late Quaternary foraminiferal record from the Great Australian Bight and its environmental significance. Memoir of the Association of Australasian Palaeontologists, 15: 417-428.

Beattie, A. 1995. Biodiversity: Australia's Living Wealth. Reed Books, Sydney.

Berggren, W. A., Aubert, J. \& Tjalsma, R. C. 1975. Paleocene benthic foraminiferal biostratigraphy, paleobiogeography and paleoecology of Atlantic-Tethyan regions. Palaeogeography, Palaeoclimatology, Palaeoecology, 18: 72-192.

Boltovskoy, E., Giussani, G., Watanabe, S. \& Wright, R. 1980. Atlas of Benthic Shelf Foraminifera of the Southwest Atlantic. Dr. W.Junk by Publishers, The Hague.

Buzas, M. A. \& Culver, S. J. 1984. Species duration and evolution: benthic foraminifera on the Atlantic continental margin of North America. Science, 225: 829-830.

Buzas, M. A. \& Culver, S. J. 1989. Biogeographic and evolutionary patterns of continental margin benthic foraminifera. Paleobiology, 15: 11-19.

Buzas, M. A. \& Culver, S. J. 1991. Species diversity and dispersal of benthic foraminifera. BioScience, 41: 483-489.

Carter, A. N. 1958. Tertiary foraminifera from the Aire District, Victoria. Geological Survey of Victoria Bulletin, 55: 1-76.

Carter, A. N. 1964. Tertiary foraminifera from Gippsland, Victoria, and their stratigraphical significance. Memoir of the Geological Survey of Victoria, 23: 1-154.

Carter, A. N. 1990. Time and space events in the Neogene of southeast Australia. In Tsuchi, R. (Ed.), Pacific Neogene Events: their timing nature and interrelationship. University of Tokyo Press, 183-194.

Chapman, F. 1907. Recent Foraminifera of Victoria: some littoral gatherings. Journal of Quekett Microscopic Club, 10: 117-146.

Chapman. F. 1941. Report on foraminifera soundings and dredgings of the F.I.S. Endeavour along the continental shelf of S.E. coast of Australia. Transactions of the Royal Society of South Australia, 65: $145-211$

Chapman, F., Parr, W. J. \& Collins, A. C. 1934. Tertiary foraminifera from Victoria, Australia. Part III. The Balcombian Deposits of Port Phillip. Journal of the Linnean Society of London (Zoology), 38: 553-577.

Chaproniere, G. C. H. 1984. Oligocene and Miocene larger Foraminiferida from Australia and New Zealand. BMR Bulletin Australian Geology and Geophysics, 188: 1-98.

Cockbain, A. E. 1967. Asterocyclina from the Plantagenet Beds near Esperance, W.A. Australian Journal of Science, 30: 68-69

Cockbain, A. E. 1978. Discocyclinid foraminifers from the Plantagenet Group, Western Australia. Annual Report of the Geological Survey of Western Australia, 1973: 107-108.

Crespin, I. 1948. Indo-Pacific influences in Australian Tertiary 
foraminiferal assemblages. Transactions of the Roval Society of South Australia, 72: 133-142.

Crespin, I. 1950. Some Tertiary foraminifera from Victoria, Australia. Contributions from the Cushman Foundation for Foraminiferal Research, 1: 70)-75.

Cresswell, G. R. 1991. The Leeuwin Current-observations and recent models. Journal of the Roval Society of Western Australia, 74: $1-14$.

Darragh, T. A. 1985. Molluscan biogeography and biostratigraphy of the Tertiary of southern Australia. Alcheringa, 9: 83-116.

Glaessner, M. F. \& Wade, M. 1959. Revision of the foraminiferal family Victoricllidac. Micropaleontology, 5: 193--212.

Haq, B. U., Hardenbol, J. \& Vail, P. R. 1987. The new chronostratigraphic basis of Cenozoic and Mesozoic sea level cycles. Special Publication. Cushman Foundation for Foraminiferal Research, 24: 7-13.

Heath. R. S. \& McGowran, B. 1984. Neogene datum planes: foraminiferal successions in Australia with reference sections from the Ninety-east Ridge and the Ontong-Java Plateau. In Ikebe, N. \& Tsuchi, R. (Eds), Pacific Neogene Datum Planes: Contributions to Biostratigraphy and Chronology. University of Tokyo Press, 187-192.

Hornibrook, N. de B. 1961. Tertiary foraminifera from Oamaru District (N.Z.). Part 1-Systematics and Distribution. New Zealand Geological Sumey Paleontological Bulletin, 34: 1-192.

Hornibrook, N. de B.. Brazier, R. C. \& Strong, C. P. 1989. Manual of New Zealand Permian to Pleistocene Foraminiferal Biostratigraphy. New Zealand Geological Survey Paleontological Bulletin, 56: $1-175$.

Howchin, W. 1889. The foraminitera of the older Tertiary of Australia (No. 1, Muddy Creek. Victoria). Transactions of the Royal Society of South Australia, 12: 1-20.

Jenkins, D. G. 1960. Planktonic foraminifera from the Lakes Entrance oil shaft, Victoria, Australia. Micropaleontology, 6: $345-371$.

Johnson, J. G. 1974. Extinction of perched faunas. Geology, 2: $479-482$.

Kaufman, E. 1987. The uniformitarian albatross. Palaios, 2: 531.

Kennett. J. P. \& Barker. P. F. 1990. Latest Cretaceous to Cenozoic climate and oceanographic developments in the Weddell Sea, Antarctica: an ocean-drilling perspective. In Barker, P.F. Kennett, J.P. et al., Proceedings of the Ocean Drilling Program, Scientific Results, 113: 937-960.

Li. Q. \& McGowran. B. 1994. Evolutionary morphological changes in the new genus Duoforisa: implications for classification and habitat of the unilocular foraminifera. Alcheringa, 18: 121-134.

Li, Q. \& McGowran, B. 1995. Comments on some southern Australian foraminifera and description of the new genus farredicta. Transactions of the Royal Society of South Australia, 119: $99-112$.

Li, O. \& McGowran, B. 1996. Benthic foraminiferal response to the Miocene oscillation on a mid-latitude margin: Lakes Entrance, southern Australia. Micropaleontology, 42: in press.

Li, Q., McGowran. B., James, N.P., Bone, Y. \& Cann, J. 1996. Mixed foraminiferal biofacies on the mesotrophic. mid-latitude Lacepede Shelf. South Australia. Palaios, 11: 176-191.

Lindsay, J. M. 1985. Aspects of South Australian Tertiary foraminiferal biostratigraphy, with emphasis on studies of Massilina and Subbotina. South Australia Department of Mines and Energy Special Publication. 5: 187-231.

Loeblich. A. R., Jr. \& Tappan, H. 1987. Foraminiferal Genera and their Classification. Van Nostrand Rcinhold. New York (2 vols).

Loutit, T. S. 1981. Late Miocene paleoclimatology: Subantarctic water mass, Southwest Pacific. Marine Micropaleontology, 6: $1-27$.

Ludbrook. N. H. 1961. Stratigraphy of the Murray Basin in South Australia. Bulletin of the Geological Sunvey of South Australia, 36: $1-96$.

Malumian, N. 1978. Esbozo palaeoecologico de las Asociaciones Foraminiferologicas Terciarias de la Argentina. Ameghiniana, 15: $161-171$.

Malumian, N. 1989. Foraminiferos Bentonicos de la Localidad Tipo de la Formacion la Despedida (Eoceno, Isla Grande de Tierra del Fuego). Parte 1: Textulariina y Miliolina. Ameghiniana, 25: $341-3.56$.

Malumian. N. 1990). Foraminiferos de la Foramacion Man Aike (Eoceno. Sureste Lago Cardiel) Provincia de Santa Cruz. Asociacion Geologica Argentina, Rev. 45: 365-385.

Malumian, N. \& Nañez, C. 1988. Asociaciones de Foraminiferos del Terciaro Medio de Cuenca Austral: sus relaciones con Eventos Eustaticos Globales. Asociacion Geologica Argentina, Rev. 43: 257-264.

McGhee, G. R., Jr., Bayer, U. \& Seilacher, A. 1991. Biological and evolutionary responses to transgressive-regrassive cycles. In Einsele, G., Ricken, W. \& Seilacher, A. (Eds), Cycles and Events in Stratigraphy. Springer-Verlag. Berlin, 696-708.

McGowran, B. 1964. Foraminiferal evidence for the Paleocene age of the Kings Park Shale, (Perth Basin. Western Australia). Journal and Proceedings of the Royal Society of Western Australia. 47: 81-86.

McGowran, B. 1965. Two Paleocene foraminiferal faunas from the Wangerrip Group, Pebble Point coastal section, western Victoria. Proceedings of the Royal Society of Victoria, 79: 2-74.

McGowran, B. 1979. The Australian Tertiary: foraminiferal overvicw. Marine Micropalentology, 4: 235-264.

McGowran, B. 1986. Cainozoic oceanic and climatic events: the Indo-Pacific foraminiferal biostratigraphic record Palaeogeography, Palaeoclimatology, Palaeoecology, 55: 247-265.

McGowran, B. 1990. Fifty million years ago. American Scientist, 78: $30-39$.

McGowran, B. 1991a. Maastrichtian and early Cainozoic, southern Australia: foraminiferal biostratigraphy. In Williams, M. A. J., de Deckker, P. \& Kershaw, A. P. (Eds), The Cainozoic in Australia: a Re-appraisal of the Evidence. Geological Society of Australia Special Publication, 18: $79-98$.

McGowran, B. 1991b. Evolution and environment in the early Palacogene. Memoir of the Geological Society of India, 20: 21-53.

McGowran, B. 1992. Eocene patterns and process. Encyclopedia of Earth System Science, Academic Press, 2: 163-176.

McGowran, B. \& Beccroft, A. 1986a. Foraminiferal biofacies in a silica-rich neritic sediment, late Eocene, South Australia. Palarogeography, Palaeoclimatology, Palaeoecology, 52: 321-345.

McGowran, B. \& Beecroft, A. 1986b. Neritic, southern extratropical foraminifera and the Terminal Eocene Event. Palaeogeography, Palaeoclimatology, Palaeoecology, 55: 23-34.

McGowran, B. \& Li, O. 1993. Miocene planktonic foraminifera from Lakes Entrance in Gippsland: Midlatitude neritic signal from a transforming ocean. Memoir of the Association of Australasian Palaeontologists, 15: 395-405.

McGowran, B. \& Li, Q. 1994. The Miocene oscillation in southern Australia. Records of the Sother Australian Museum, 27: 197-212.

McGowran, B., Moss, G. \& Beecroft, A. 1992. Late Eocene and early Oligocene in southern Australia: local neritic signals of global oceanic changes. In Prothero, D.R. \& Berggren, W. A. (Eds), Eocene-Oligocene Climatic and Biotic Evolution. Princeton University Press, 178-201.

Moss. G. \& McGowran. B. 1993. Foraminiferal turnover in neritic environments: the end-Eocene and mid-Oligocene events in southern Australia. Memoir of the Association of Australasian Palaeontologists, 15: 407-416.

Olsson, R. \& Usmani, P.A. 1992. Upper Cretaceous foraminiferain Santonian to Maestrichtian depositional sequences in the New Jersey Coastal Plain. In Ishizaki. K. \& Saito, T. (Eds), Centenary of Japanese Micropaleontology: Contributed Papers in Honor of Professor Yokichi Takayanagi, Terra Scientific Publishing Co., Tokyo, 310-315.

Parr, W. J. 1932. Victorian and South Australian shallow-water foraminifera. Proceedings of the Royal Society of Victoria (new series), 44: 1-14.

Parr, W. J. 1938. Upper Eocene foraminifera from deep borings in Kings Park, Perth, Western Australia. Journal and Proceedings of the Royhal Society of Western Australia, 24: 69-101.

Parr. W. J. 1939. Foraminifera of the Pliocene of south-eastern Australia. Mining and Geological Journal, 1: 65-71. 


\section{S. Australian foraminifera}

Parr, W. J. 1942. New genera of foraminifera from the Tertiary of Victoria. Mining and Geological Journal, 2: 361-364.

Parr, W. J. 1950, Foraminifera. Reports of the B.A.N.Z. Antarctic Research Expedition 1929-1931, Adelaide, Series B (Zoology and Botany), 5: 223-392.

Prentice, M. L. \& Matthews, R. K. 1991. Tertiary ice sheet dynamics: The snow gun hypothesis. Journal of Geophysical Research, 96: 6811-6827.

Quilty, P. G. 1969. Upper Eocene planktonic Foraminiferida from Albany, Wstern Australia. Journal of the Royal Society of Western Australia, 52: 41-58.

Quilty, P. G. 1972. The biostratigraphy of the Tasmanian marine Tertiary. Papers and Proceedings of the Royal Society of Tasmania, 106: $25-44$.

Quilty, P. G. 1974. Tasmanian Tertiary foraminifera. Part 1. Textulariina. Miliolina, Nodosariacea. Papers and Proceedings of the Royal Society of Tasmania, 108: 31-106.

Quilty, P. G. 1977a. Tasmanian Tertiary foraminifera. Part 2. Chiefly Spirillinacea to Glabratellidae. Papers and Proceedings of the Royal Society of Tasmania, 110: 69-109.

Quilty, P. G. 1977b. Cenozoic sedimentation cycles in Western Australia. Geology, 5: 336-340.

Quilty, P. G. 1980. New rotalid foraminifera from the Oligo-Miocene of Tasmania. Alcheringa, 4: 299-311.

Ouilty, P. G. 1981. Late Eocene benthic Foraminiferida, south coast. Western Australia. Journal of the Royal Society of Western Australia, 64 (3): 79-100.

Quilty, P. G. 1982. Tasmanian Tertiary foraminifera. Part 3. Discorbacea (Eponididae) to Nonionacea. Papers and Proceedings of the Royal Society of Tasmania, 116: 5-52.

Quilty, P. G. 1985. A Pliocene foraminiferid fauna from Flinders Island, Bass Strait. Papers and Proceedings of the Royal Society of Tasmania, 119: 89-91.

Quilty, P. G. 1992. Evolution of the modern glaciation of Antarctica. In Quilty, P. G. (Ed) Impact of global change: Antarctica. Department of the Arts, Sport, the Environment and
Territories, Canberra, 10-16

Quilty, P. G. \& Telfer, A. 1994. Marine Neogene samples from around Tasmania: an extension to the Miocene/Pliocene marine record in Tasmania. Papers and Proceedings of the Royal Society of Tasmania. 128: 41-56.

Rollins, H. B., Carothers, M. \& Donahue, J. 1979. Transgression. regression and fossil community succession. Lethaia, 12: 89-104.

Shubber, B., Bone, Y., McGowran, B. \& James, N.P. 1994. Tertiary cool-water carbonate depositional facies: St. Vincent Basin, South Australia. Geological Society of Australia Abstracts, 37: 407.

Truswell, E. M. 1990. Australian rainforests: the 100 million year record. In Webb, L. J. \& Kikkawa, J. (Eds), Australian Tropical Rainforests: Science-Value-Meaning. CSIRO Australia, Melbourne, 7-22.

Valentine, J. W. \& Jablonski. D. 1983. Speciation in the shallow sea: general patterns and biogeographic controls. In Sims, R. W., Price, J.H. \& Whalley, P. E. S. (Eds), Evolution, Time and Space: the Emergence of the Biosphere. The Systematic Association Special Volume, Academic Press, London, 23: 201-226.

Veevers, J. J. (Ed.) 1984. Phanerozoic earth history of Australia. Clarendon Press, Oxford.

Vella, P. 1957. Studies in New Zealand foraminifera. Part I Foraminifera from Cook Strait. Part II-Upper Miocene to Recent species of the genus Notorotalia. New Zealand Geological Survey Paleontological Bulletin, 28: 1-64.

Walker, P. M. B. (Ed.) 1988. Chambers science and technology dictionary. W. \& R. Chambers Ltd, Cambridge.

Webb, P.-N. 1990. The Cenozoic history of Antarctica and its global impact. Antarctic Science, 2: 3-21.

Webb, P.-N. \& Harwood, D.M. 1987. The terrestrial flora of the Sirius Formation: Its significance in interpreting Late Cenozoic glacial history. Antarctic Journal of the United States, 22: 7-11.

Wilson, B.R. \& Allen, G.R. 1987. Major components and distribution of marine fauna. In Dyne, G.R. \& Walton, D.W. (Eds), Fauna of Australia. General Articles. Australian Government Publishing Service, Canberra, 1A: 43-68. 


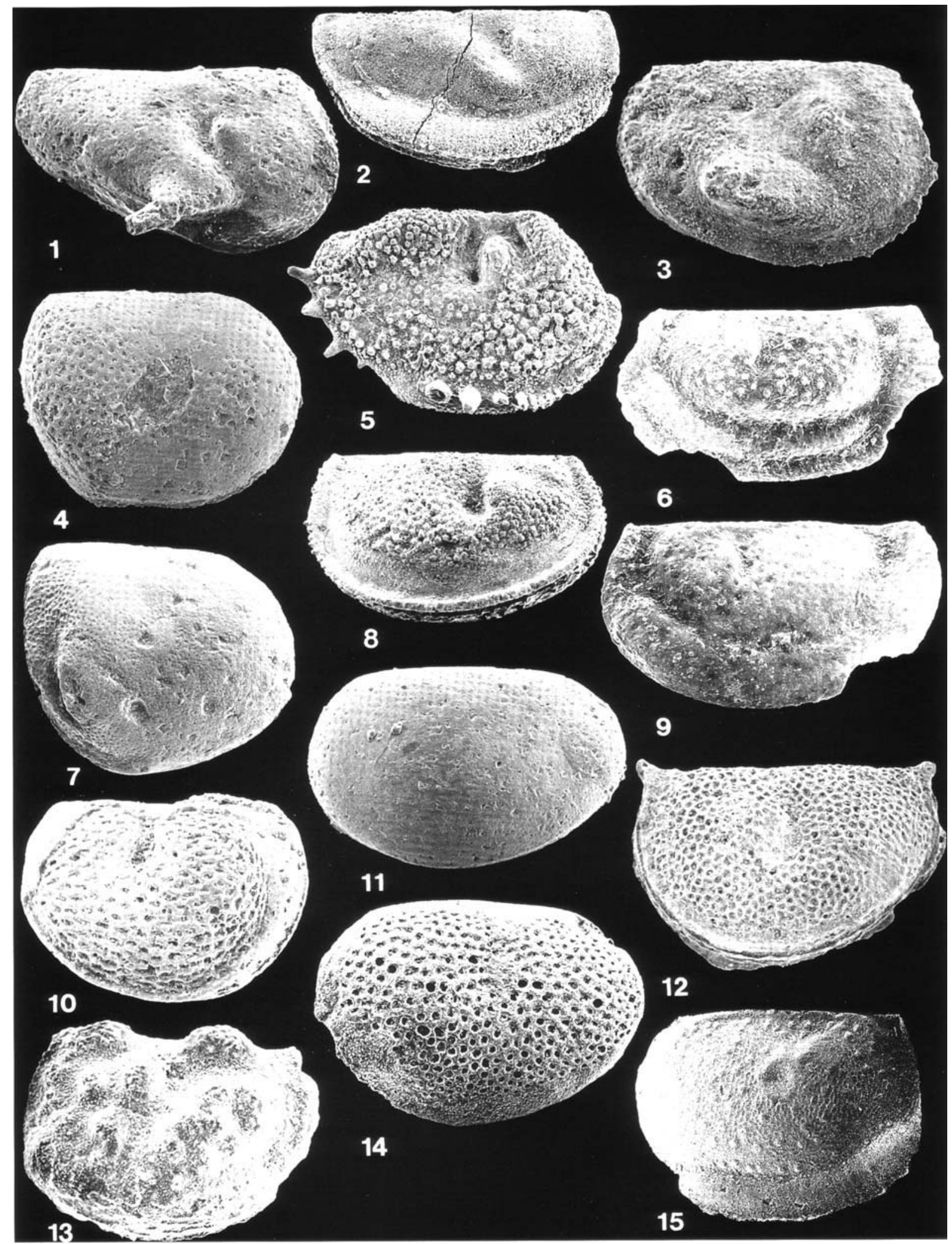

Plate 1, reprinted from Williams. M. \& Siveter, D. J. 1996. Lithofacies-influenced ostracod associations in the middle Ordovician Bromide Formation, Oklahoma, USA. Journal of Micropalaeontology, 15: 69-81. For Explanation of Plate 1, please see p. 75 of the above article. 